\title{
Digitising Patterns of Power
}

\author{
An Interactive Map-Based Application to Represent historical Landscapes
}

Markus Breier [1], Adam Mertel [2], Karel Kriz [1] \& Alexander Pucher [1]

[1] University of Vienna, Department of Geography and Regional Research

markus.breier@univie.ac.at, karel.kriz@univie.ac.at, alexander.pucher@univie.ac.at https://homepage.univie.ac.at/karel.kriz/

[2] Masaryk University, Faculty of Science, Department of Geography

mertel.adam@mail.muni.cz

Keywords: Cartographic Communication, Cartographic Visualization, Spatial Uncertainty, HGIS, Historical Landscape

\begin{abstract}
The ÖAW project "Digitising Patterns of Power" (DPP) brings together archaeology, historical research and digital cartography and geocommunication. The communication of space, time and spatial interconnectivity is an essential aspect of the project. An interactive map-based application provides a visual frontend for various aspects of DPP.
\end{abstract}

\section{Introduction}

The perception, depiction and organization of spaces and places in the Middle Ages encompass an interdisciplinary research field which helps to understand historical processes within the medieval period. The representation of space in medieval texts, the appropriation of land and the subsequent installation of new power-structures are central research topics of the project "Digitizing Patterns of Power - Peripherical Mountains in the Medieval World" (DPP). ${ }^{1}$

Patterns of power, established in space and time, are the research focus of DPP. It is a multidisciplinary project, conducted by the Institute for Medieval Research (IMAFO) of the Austrian Academy of Sciences in cooperation with the University of Vienna, Department of Geography and Regional Research (IfGR). The research questions are the domain of historical scholarship, but the phenomena are to a large extent spatial phenomena. The representation and analyses of spatial phenomena are core competences of cartography and geographical information science. The aim of DPP is the development of a generalizable workflow from the digitization of a specific corpus of textual and archaeological evidence to the analysis and visualization of data with the help of digital tools. These requirements led to a map-based online application, which allows the user to visually explore the historical landscape.

Cartography and geocommunication are vital parts in the representation and visualization of the histor-

1 https://dpp.oeaw.ac.at/ (12.06.2019). 
ical landscape and the underlying data. ${ }^{2}$ The creation of project-specific base maps, the visualization of the uncertainty inherent in historical data and the development of methods of interactive geocommunication to create a sustainable online presentation of data and results of the research are central for DPP.

This paper focuses on the geocommunication and visualisation aspects of the project. Other aspects of the project are covered by an edited volume. ${ }^{3}$

\section{Case Studies and historical research questions}

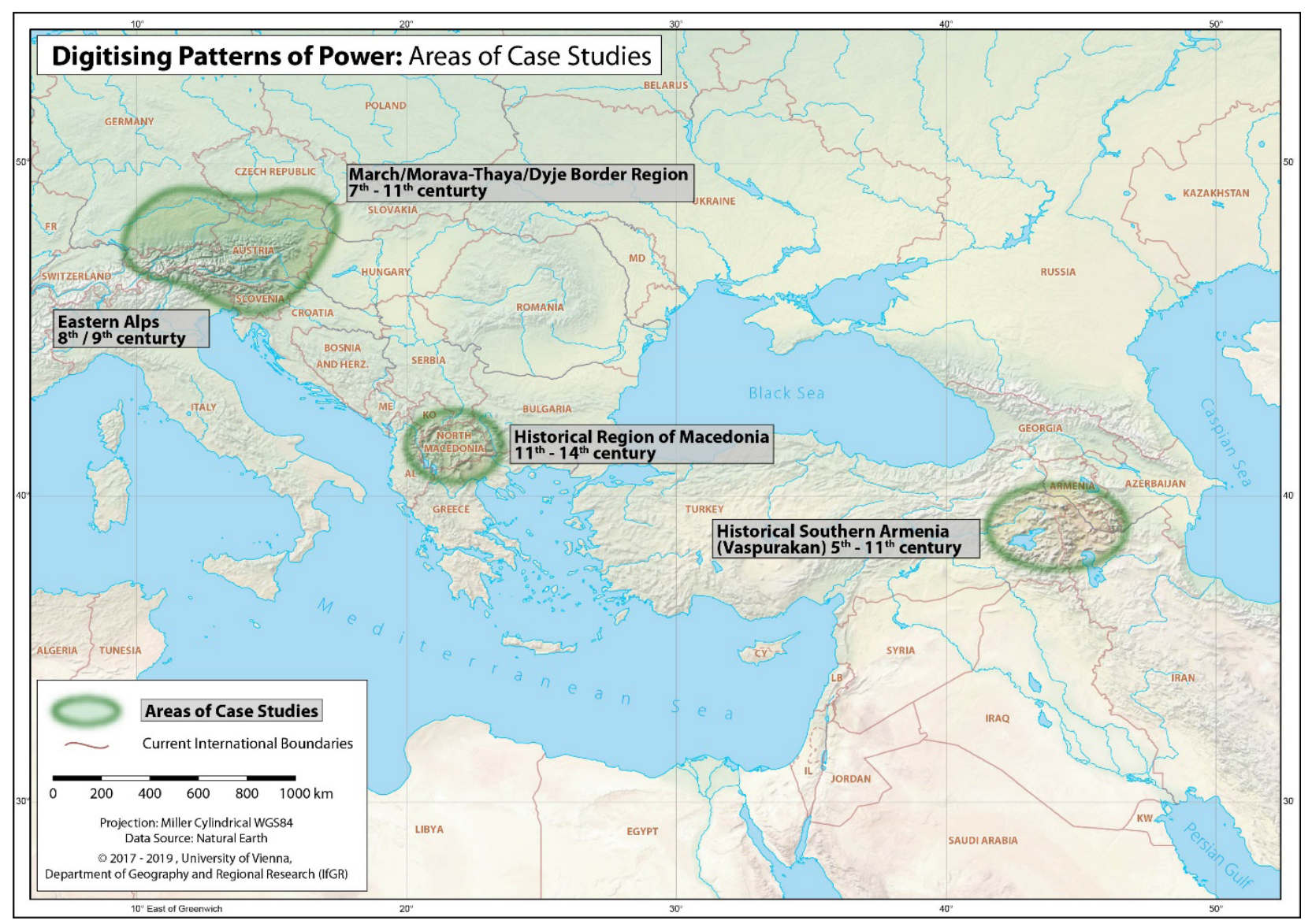

Fig. 1: The case studies of DPP

The project will focus on four case study regions. Historical research questions come from these.

- The Carolingian eastern Alps (8th/9th century)

- The March/Morava - Thaya/Dyje border region (7th-11th century)

- The historical region of Macedonia (12th-14th century)

- Historical southern Armenia: the rise and fall of Vaspurakan (5th-11th century)

2 David J. Bodenhamer / John Corrigan / Trevor M. HARris, Hg., The spatial humanities. GIS and the future of humanities scholarship, Bloomington 2010; Ian N. GREGORY / Paul S. ELL, Historical GIS. Technologies, methodologies and scholarship, 2. Auflage, Cambridge 2012.

3 Mihailo Popovıć u. a., Hg., Power in Landscape - Geographic and Digital Approaches in Historical Research, Leipzig 2019. 
The common research topic is the appropriation of space through creating "places of power" and possible underlying strategies.

In the eastern Alps and its surroundings, different structures were established in the late Roman Empire, the Carolingian expansion in the 8th and 9th century and the medieval internal colonization of the Eastern Alps region starting from the 10th century. Ecclesial institutions vied for influence to control the trade and pilgrimage routes to the south. ${ }^{4}$

The Morava/Thaya region is and has always been a border region not only today, but also during the medieval age. The political and social entities on both sides of the border have left certain patterns of power in the landscape. Due to the lack of historical sources in this case study the focus is on archaeological sources. ${ }^{5}$

At the territory of today's North Macedonia, research is conducted on the transformation of the region from a Byzantine province into an area of military and political expansion by the Serbian medieval empire. Impacts on settlement patterns, redistribution of landed property, interplay between resident population and nomads and the establishment of new infrastructure are of interest. ${ }^{6}$

In the historical territory of southern Armenia, research focuses on the region around Lake Van and on the emergence of the principality of the noble house of Arcruni in the period between the end of the ancient Armenian monarchy (428) and the Seljuk conquest of Armenia (1020-1070). A comprehensive analysis of the construction of an early medieval polity at the Van region at the crossroads between Byzantium and the Islamic World is the aim of this case study. ${ }^{7}$

DPP builds on information and data gathered by the project partners from the Academy of Sciences and comprises of archaeological and historical sources. Archaeological entities include artefacts, monuments, settlements, and burial sites; historical information is extracted from written sources like charters, chronicles and travel reports. This information is geotagged and entered in a common database.

\section{Base Maps}

To provide a background for the historical information, a specific base map was created, which suits the needs of the historians and archaeologists. Ideally, the map should represent the landscape at the timeframe appropriate for the research question. However, there were some difficulties to this undertaking. For one, it is very problematic to near impossible to get geodata of the medieval landscape. Not only man-made features like settlements and land use have changed, but also natural features like the course of rivers, coastlines and the extent of lakes have changed during history. Although there has been research on historical courses of some rivers, there is no comprehensive and consistent data

$4 \quad$ Katharina WINCKLER, Die Alpen im Frühmittelalter, Wien 2012.

5 Stefan EıснеRт, Frühmittelalterliche Strukturen im Ostalpenraum. Studien zu Geschichte und Archäologie Karantaniens, Klagenfurt am Wörthersee 2012.

6 Mihailo Popovıć, Vlachen in der historischen Landschaft Mazedonien im Spätmittelalter und in der Frühen Neuzeit, in: Walter Pohl u. a., Hg., Walchen, Romani und Latini: Variationen einer nachrömischen Gruppenbezeichnung zwischen Britannien und dem Balkan, Wien 2017, 183-196.

7 Johannes PREISER-KAPELLER, erdumn, ucht, carayut'iwn. Armenian aristocrats as diplomatic partners of Eastern Roman Emperors, 387-884/885 AD, in: The Armenian review 52 (2010), 139-215; Johannes PREISER-KAPELLER, Networks of border zones: multiplex relations of power, religion and economy in South-eastern Europe, 1250-1453 CE, in: Proceedings of the 39th Annual Conference of Computer Applications and Quantitative Methods in Archaeology, Revive the Past (CAA) in Beijing, China, Amsterdam 2012, 381-393. 
available for all relevant regions. Furthermore, the project spans a timeframe of ten centuries, from the 5th to the 14th century. Overall, it was decided that the base map of DPP is based on current geodata, which will serve as a viable approximation.

To take various prerequisites by different partners and user-groups into consideration, two base maps are available. The default base map is without current borders and cities, focusing on relief, waterbodies and land use. An alternative version is available, which includes the international borders, important cities and the according labels. In higher zoom levels, the current road network is also included. Both base maps are created from free geodata and offer scale-dependent design. Furthermore, the maps of the "Tabula Imperii Byzantini" are integrated as additional map layers.

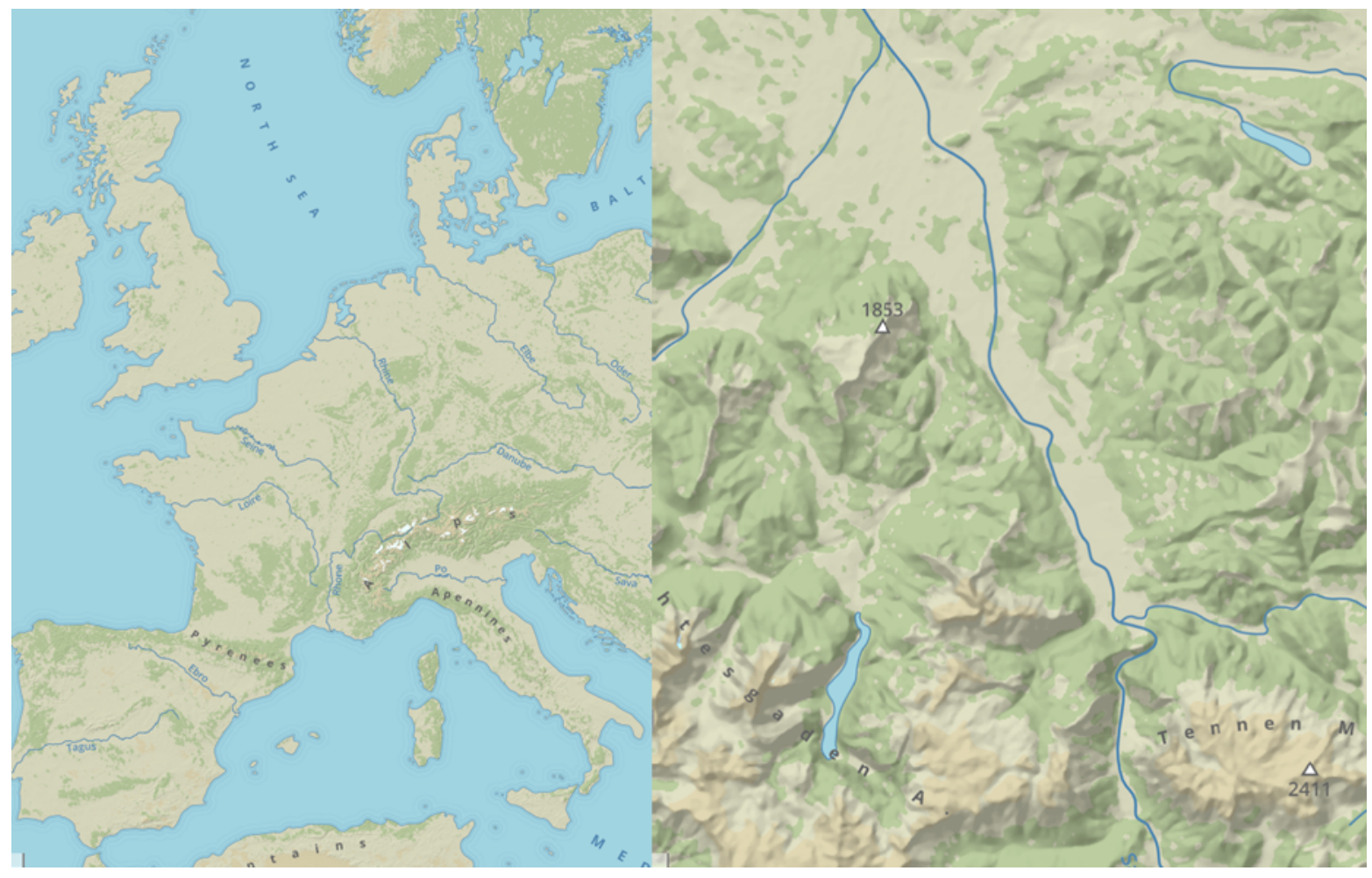

Fig. 2: Base map without modern features. Zoom level 5 (left) and zoom level 11 (right) 


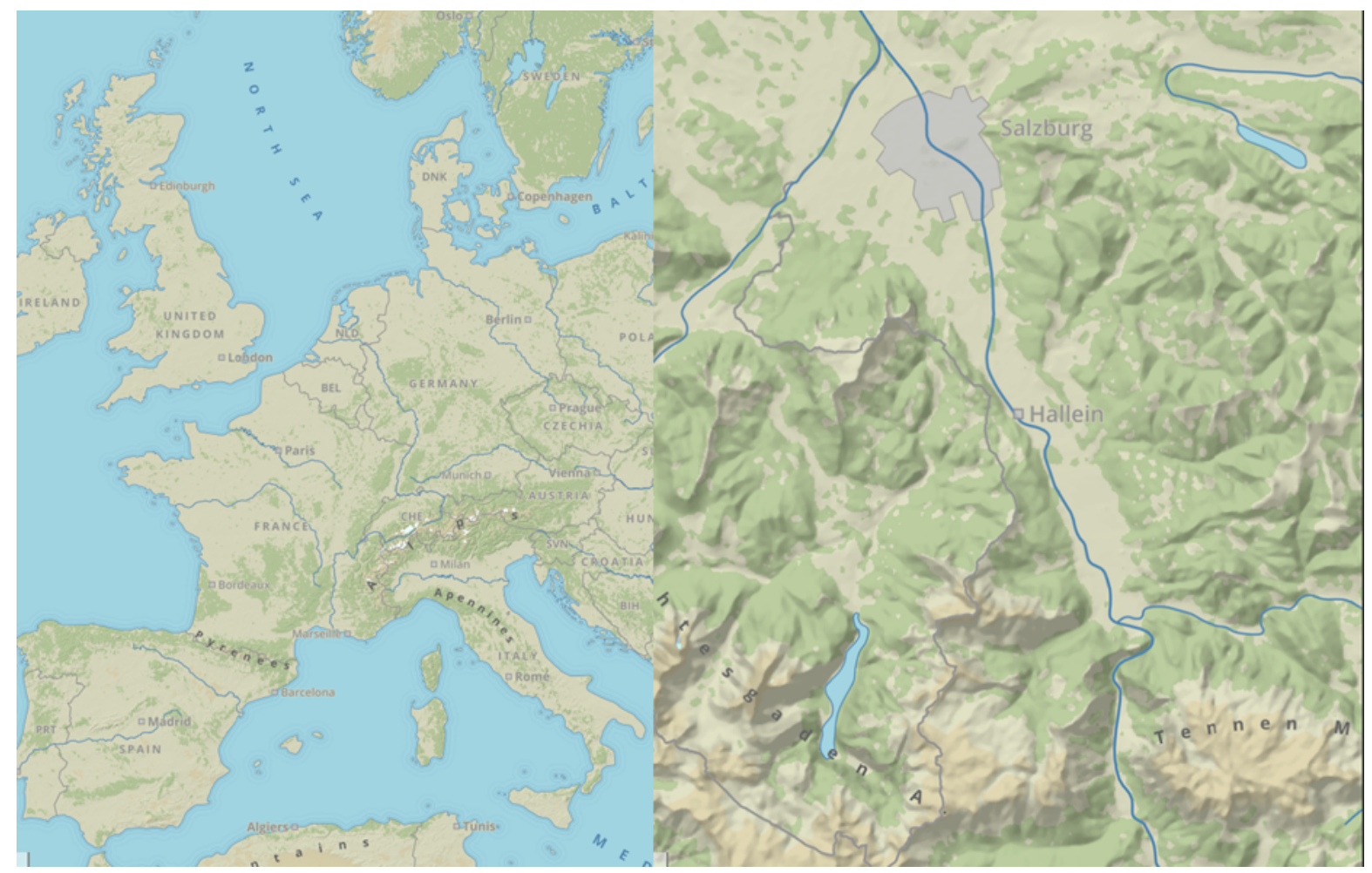

Fig. 3: Base map with modern features. Zoom level 5 (left) and zoom level 11 (right)

\section{Spatial Uncertainty of Historical data}

Due to the nature of the data sources, the spatial data quality varies greatly, especially accuracy and certainty. Data extracted from written sources is most of the times imprecise and uncertain. The references in the written sources are often very vague, e.g. a location was in the vicinity of a town or situated nearby a geographical feature. This is further complicated by the fact that the entity, which the location is referenced to, can be located only vaguely itself. The exact extent of historical administrative units or the area of influence is very hard to determine. Such historical entities were often not clearly defined even during the time they existed. These uncertainties make it difficult to give exact coordinates to the events and locations. Furthermore, the uncertainty has to be represented scale dependent in the map-based application. Approximation methods, like assigning the data to the centre of the current administrative unit or guessing where the location was most likely, are not desirable for this project. Therefore, approaches to make this uncertainty visible were investigated during the project. Although various approaches to uncertainty visualization exist, ${ }^{8}$ these approaches had to be adapted for the use in an interactive application with many different data entities.

In DPP, fuzzy polygons are used to represent uncertain locations. These polygons are an interpretation by the researcher entering the data and are created manually during data input.

8 Alan M. MACEACHREN u. a., Visual Semiotics \& Uncertainty Visualization: An Empirical Study, in: IEEE transactions on visualization and computer graphics 18/12 (2012), 2496-2505. Anne-Kathrin REUSCHEL / Lorenz HuRNI, Mapping Literature. Visualisation of Spatial Uncertainty in Fiction, in: The Cartographic Journal 48/4 (2011), 293-308. 


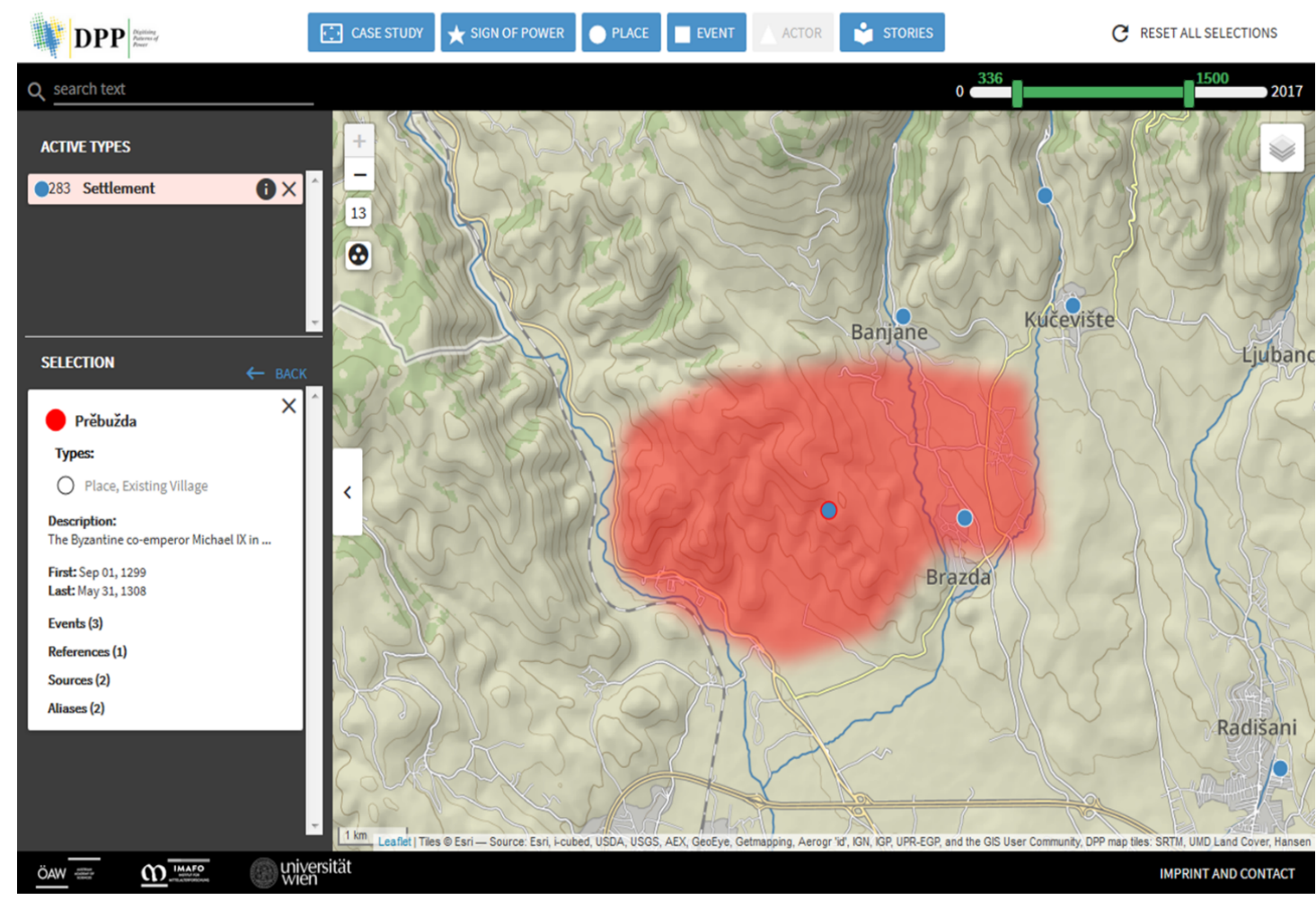

Fig. 5: Visualisation of uncertain locations in DPP

\section{Geocommunication}

The map-based application serves as a tool for research itself. By enabling the user to combine various datasets and results of database queries, spatial relations can be explored.

However, it was not the aim of DPP to create a web-based geographical information system (GIS). DPP focuses on optimal representation of the data and its uncertainty as well as on usability, especially for non-GIS experts and performance. ${ }^{9}$ The application guides the user through the data, allowing to query the database and show various data layers over a purpose made base map.

The application offers a basic query interface for database and navigation to provide a first look at the data available in the database. A time slider allows the user to gain insight to the temporal aspects. For more complex queries, a query builder is available, which allows the user to search and filter for more advanced criteria.

$9 \quad$ Karel KRIZ, Maps and Design-Influence of Depiction, Space and Aesthetics on Geocommunication, in: Karel Kriz u. a., Hg., Understanding Different Geographies, Berlin / Heidelberg 2013, 9-23. 


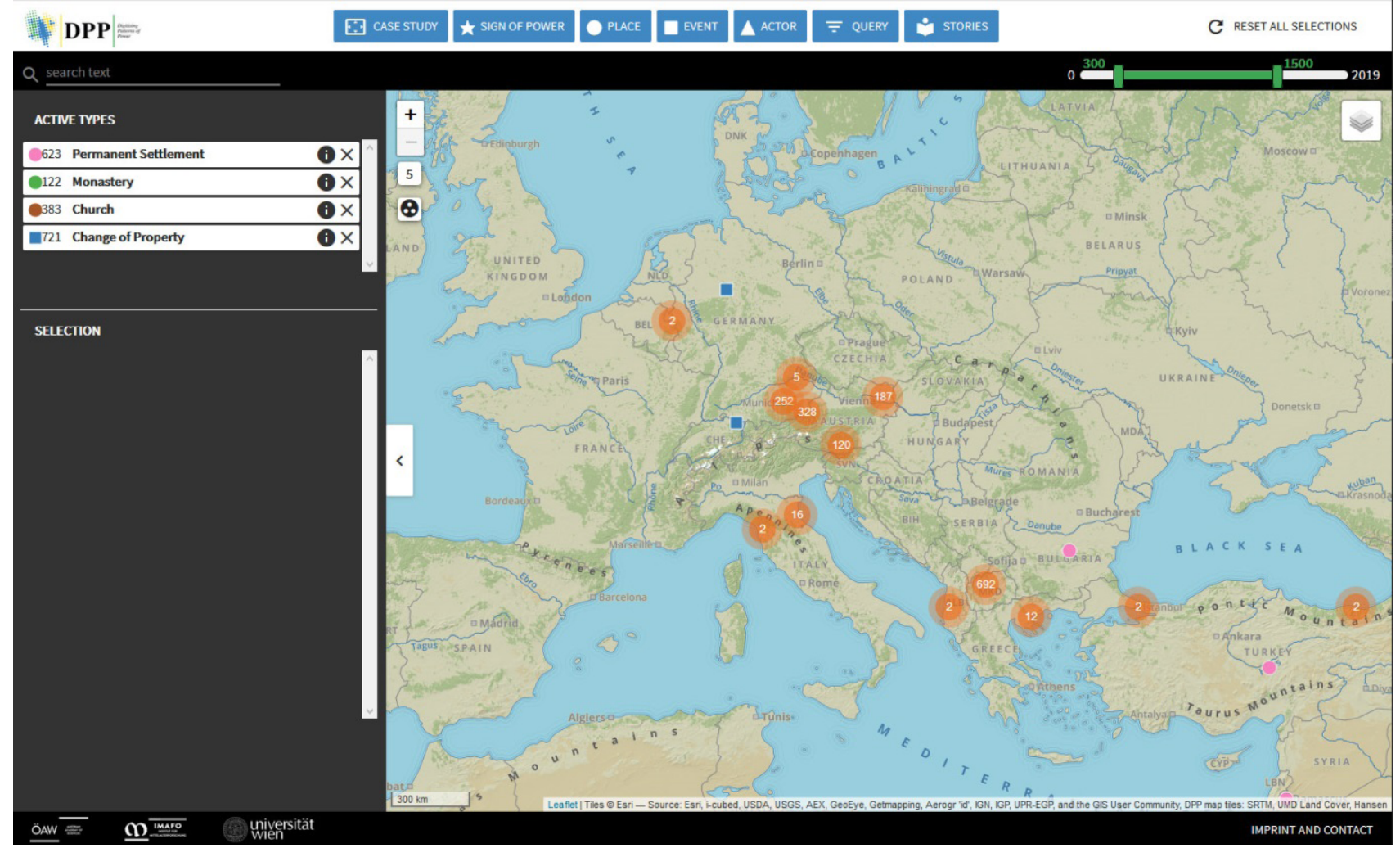

Fig. 6: The map-based application of DPP

Data entities are displayed as dots and are clustered, because there are areas with very high data density. The clustering can be turned off to show the actual distribution of entities. Once an object is selected, the uncertainty information is shown. The links between various data entities like places, events, actors and signs of power can be followed via hyperlinks, which allows to explore relations between entities. With these tools, the data can be explored in its spatial, temporal and thematic aspects to help in answering the historical research question.

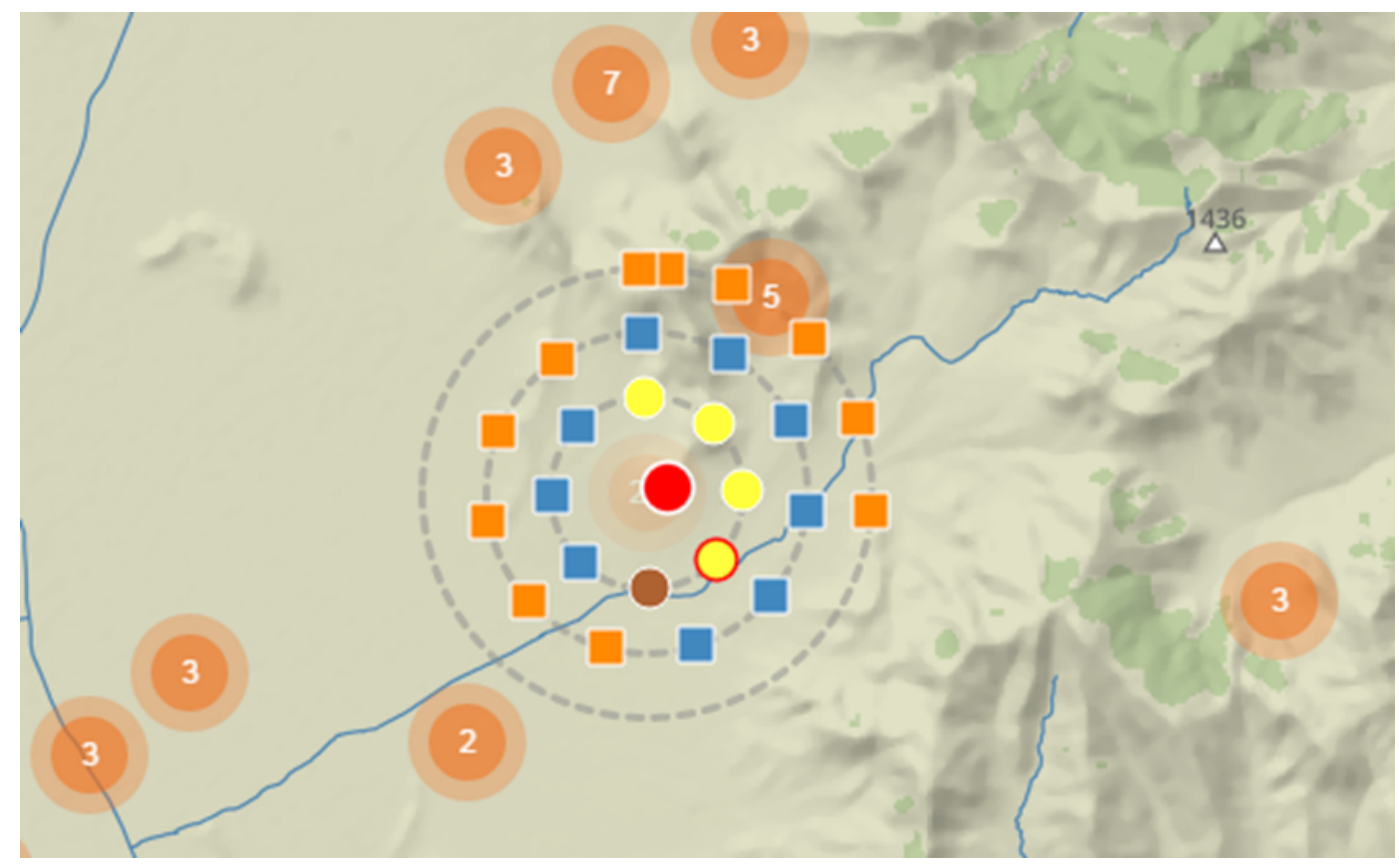

Fig. 7: Clustering in the DPP application 
To communicate key results of the project to the public, so called "Story Maps" are included in the application. These "Story Maps" are predefined views of the data which are complemented with a detailed description of the topic shown and information about its significance for the historiography.

\section{Conclusion}

DPP is a multidisciplinary research project which explores the benefits of state-of-the-art geocommunication technologies to historical research. The focus of the cartographic efforts of the project lies on inherent cartographic issues, which are until now hardly considered in similar projects.

DPP uses high quality base maps, which are created specifically for this project. Story maps and database query functions allow researchers as well as the interested public to browse the data and explore the spatial relations of the entities of the case studies as well as to see the results of the research. The uncertainty of the various entities is also modelled in the database and is represented in the map view.

When designing such a system, usability has to be considered. The aim was to create a flexible system, where the user can conduct her or his own queries and combination of layers. However, it is also easy to use for non-GIS experts. Due to the modular architecture, the framework can be extended with new functionality and used within various similar projects in the future.

\section{Literature}

David J. Bodenhamer / John Corrigan / Trevor M. Harris, Hg., The spatial humanities. GIS and the future of humanities scholarship, Bloomington 2010.

Stefan EICHERT, Frühmittelalterliche Strukturen im Ostalpenraum. Studien zu Geschichte und Archäologie Karantaniens, Klagenfurt am Wörthersee 2012.

Ian N. Gregory / Paul S. ElL, Historical GIS. Technologies, methodologies and scholarship, 2. Auflage, Cambridge 2012.

Karel KRIz, Maps and Design-Influence of Depiction, Space and Aesthetics on Geocommunication, in: Karel Kriz u. a., Hg., Understanding Different Geographies, Berlin / Heidelberg 2013, 9-23.

Alan M. MACEACHREN U. a., Visual Semiotics \& Uncertainty Visualization: An Empirical Study, in: IEEE transactions on visualization and computer graphics 18/12 (2012), 2496-2505.

Mihailo Popović, Vlachen in der historischen Landschaft Mazedonien im Spätmittelalter und in der Frühen Neuzeit, in: Walter Pohl u. a., Hg., Walchen, Romani und Latini: Variationen einer nachrömischen Gruppenbezeichnung zwischen Britannien und dem Balkan, Wien 2017, 183-196.

Mihailo Popović u. a., Hg., Power in Landscape - Geographic and Digital Approaches in Historical Research, Leipzig 2019.

Johannes Preiser-Kapeller, erdumn, ucht, carayut'iwn. Armenian aristocrats as diplomatic partners of Eastern Roman Emperors, 387-884/885 AD, in: The Armenian review 52 (2010), 139-215.

Johannes Preiser-KapelleR, Networks of border zones: multiplex relations of power, religion and economy in South-eastern Europe, 1250-1453 CE, in: Proceedings of the $39^{\text {th }}$ Annual Conference of Computer Applications and Quantitative Methods in Archaeology, Revive the Past (CAA) in Beijing, China, Amsterdam 2012, 381-393.

Anne-Kathrin Reuschel / Lorenz HuRNI, Mapping Literature. Visualisation of Spatial Uncertainty in Fiction, in: The Cartographic Journal 48/4 (2011), 293-308.

Katharina WINCKLER, Die Alpen im Frühmittelalter, Wien 2012. 